\title{
AKT POŚWIĘCENIA NARODU POLSKIEGO NIEPOKALANEMU SERCU MARYI WEDŁUG SŁUGI BOŻEGO KARDYNAŁA AUGUSTA HLONDA
}

Przed siedemdziesięciu laty na Jasną Górę przybyło milion pielgrzymów. Jaki był powód tak licznego zgromadzenia wiernych? Prymas August Hlond wraz z biskupami dokonał aktu poświęcenia narodu polskiego Matce Bożej. Wydarzenie to miało wielkie znaczenie dla Kościoła w Polsce zagrożonego w swojej egzystencji przez ateistyczny ustrój narzucany siłą ze Wschodu. Do tego wydarzenia, w swojej publicznej działalności, wielokrotnie odwoływał się kardynał Stefan Wyszyński. Poniższy artykuł jest próbą ukazania przebiegu, przyczyn i znaczenia ślubów jasnogórskich roku 1946.

\section{1. ŚLUBY JAKO DZIEŁO CAŁEGO NARODU}

Po zakończeniu II wojny światowej A. Hlond i polscy biskupi pragnęli odnowić przymierze Polski z Jej niebieską Królową. W zamierzeniu prymasa miał to być akt poświęcenia narodu Matce Najświętszej i Jej Niepokalanemu Sercu, oddanie w Jej szczególną opiekę Kościoła i przyszłości Rzeczypospolitej.

Prymas przywiązywał ogromne znaczenie do tego, by akt ten został dokonany z wiarą i był poparty czynem prowadzącym do odnowienia życia chrześcijańskiego w wymiarze jednostek, rodzin, narodów i świata. 
Chciał, by to poświęcenie dokonało się w trzech etapach. Najpierw w niedzielę po uroczystości Nawiedzenia Maryi Panny (7 lipca) w parafiach i kościołach zakonnych, następnie w uroczystość Wniebowzięcia Najświętszej Maryi Panny (15 sierpnia) w diecezjach, a wreszcie w uroczystość Narodzenia Matki Bożej, a więc 8 września 1946 roku', w wymiarze całego narodu na Jasnej Górze. Poszczególne etapy miały służyć włączeniu w rzeczywistość ślubów wszystkich Polaków.

Centralny akt oddania zgromadził ponad milion pielgrzymów, wszystkich polskich biskupów, administratorów apostolskich i licznych kapłanów. Mszę Świętą celebrował kardynał Adam Stefan Sapieha a kazanie wygłosił bp Karol Radoński. Po Mszy Świętej i litanii loretańskiej kardynał August Hlond wypowiedział Akt uroczystego ofiarowania Polski Niepokalanemu Sercu Matki Bożej².

\section{GENEZA AKTU POŚWIĘCENIA Z 1946 ROKU}

Decyzja o dokonaniu aktu poświęcenia Polski Niepokalanemu Sercu Maryi została podjęta przez biskupów polskich, zebranych na Jasnej Górze podczas Konferencji Episkopatu, 3-4 października 1945 roku, a więc zaledwie dwa i pół miesiąca po powrocie A. Hlonda do kraju. Zamysł ten został ogłoszony w napisanym przez prymasa liście pasterskim Episkopatu z 18 lutego 1946 roku zatytułowanym O panowanie ducha Bożego w Polsce.

Prymas wyraźnie nawiązywał do ślubów króla Jana Kazimierza złożonych, jak pisał, po szwedzkim potopie ${ }^{3}$. Śluby lwowskie, jak wiemy, złożył król Jan Kazimierz Waza w katedrze Wniebowzięcia Najświętszej Maryi Panny we Lwowie 1 kwietnia 1656 roku. W tym czasie kraj prawie całkowicie opanowany był przez Szwedów i Rosjan. Śluby dokonały się zatem podczas potopu szwedzkiego.

1 Por. O panowanie ducha Bożego w Polsce. Wielkopostny list pasterski episkopatu, Poznań 18 II 1946, w: A. H lon d, W stużbie Boga i Ojczyzny. Wybór pism i przemówień 1922-1948, oprac. S. Kosiński, Warszawa 1988, s. 208-209.

2 Por. L. B a 1 t e r, Rok 1946 na Jasnej Górze, „Jasna Góra” 9 (11), s. 9-14.

3 Por. O panowanie..., dz. cyt., s. 208-209. 
A. Hlond, pisząc o ślubach po szwedzkim potopie, być może chciał uniknąć możliwości rozumienia swojej inicjatywy jako wezwania do zbrojnej walki z komunizmem a także podkreślić duchowy wymiar ślubów roku 1946.

Niewątpliwie akt z 1946 roku stanowi nawiązanie do uroczystego poświęcenia rodzaju ludzkiego Niepokalanemu Sercu Maryi, jakiego dokonał w przełomowym roku 1942, w najtrudniejszym okresie II wojny światowej, papież Pius XII, spełniając w ten sposób jedno z życzeń Pani Fatimskiej przedstawione trojgu dzieciom w Cova da Iria $^{4}$. W swoim liście pasterskim prymas wyraźnie odwołuje się do przykładu Ojca Świętego i katolickich narodów. Zachęca: „Przyłączymy się tak do powszechnego chóru, którym za najwyższą zachętą i przykładem Ojca świętego Piusa XII wszystkie katolickie narody składają hołd Najświętszej Pannie jako Królowej stworzenia i Wspomożycielce Wiernych, błagając, by ludzkość wydźwignęła z toni, a Kościół osłoniła swym wszechmocnym ramieniem”. Sam prymas przeżył poświęcenie się Francji, 22 marca 1943 roku, Niepokalanemu Sercu Maryi 6 .

Jak wiadomo lata II wojny światowej A. Hlond spędził na wygnaniu. W przededniu przystąpienia Włoch do wojny 9 czerwca 1940 roku opuścił Rzym i udał się do Lourdes, gdzie przebywał do 6 kwietnia 1943 roku7. Był to czas dojrzewania jego głębokiego zawierzenia Matce Bożej, które w okresie powojennym wyraziło się w ślubach narodu.

Wydaje się, że istnieje także związek między aktem poświęcenia z 1946 roku a oddaniem Rzeczypospolitej w opiekę Królowej Korony

4 Por. J. D r o z d, Orędzie Niepokalanej. Historia i sens objawień fatimskich, Kraków 1996, s. 133. Ściśle mówiąc, papież w 25 rocznicę objawień fatimskich dokonał dwu aktów poświecenia, a mianowicie 31 października oraz 8 grudnia 1942 roku w Bazylice św. Piotra.

5 Opanowanie..., dz. cyt., s. 209'.

6 Por. J. P i et r z a k, Petnia prymasostwa. Ostatnie lata prymasa Polski kardynała Augusta Hlonda 1945-1948, t. I, Poznań 2009, s. 356.

7 Por. S. W i 1 k, Osoba kardynała Augusta Hlonda, w: Ks. kardynat August Hlond-społeczny wymiar nauczania, red. G. Polok, Katowice 2006, s. 20. 
Polskiej, jakiego, w obliczu zagrożenia ojczyzny bolszewickim najazdem, dokonał kardynał Edward Dalbor wraz z 17 polskimi biskupami. 28 lipca 1920 roku na Jasnej Górze biskupi przyzywali ratunku Maryi, prosili o upragniony pokój, narodową zgodę, bezpieczeństwo od nieprzyjaciół.

S. Zimniak, w swoim skądinąd ciekawym opracowaniu, stwierdza, że genezy i źródła zawierzenia Hlonda należy szukać nie w ślubach Jana Kazimierza, ale w akcie Piusa XII. Taka teza wydaje się jednak iść zbyt daleko i nie uwzględnia wielości inspiracji, jakie przyczyniły się do decyzji o podjęciu aktu poświęcenia w roku $1946^{8}$.

\section{MARYJNE ŚLUBY A. HLONDA SKLADANE W OKRESIE MIĘDZYWOJENNYM}

Rozważając sens i genezę ślubów z 1946 roku, nie można pominąć ślubów maryjnych Sługi Bożego A. Hlonda składanych już w okresie międzywojennym. 18 maja 1924 roku ówczesny administrator apostolski dla Górnego Śląska przybywa na Jasną Górę wraz z pielgrzymką młodzieży śląskiej, którą ofiarowuje Matce Najświętszej. W swoim przemówieniu zachęca młodych, by ich pobożność maryjna była konsekwentna, obejmowała wszystkie wymiary życia. W imieniu młodych Śląska składa akt poświęcenia się Maryi na służbę. Wyraża pragnienie obrony czci Maryi, szerzenia chwały Jej Syna Jezusa Chrystusa. Prosi Maryję o pomoc w apostolskich wysiłkach zmierzających do religijnego odrodzenia Śląska, woła o dar świętego zapału i wytrwałości 9 .

8 Por. S. Z i m n i a k, Zwycięstwo Maryi. Proroctwo Kardynała Augusta Hlonda. W postudze apostolskiej prymasa tysiąclecia Stefana kardynała Wyszyńskiego i papieża Jana Pawła II Wielkiego, Warszawa 2007, s. 7-8.

9 Por. Ks. August Hlond na Górnym Śląsku 1922-1926. Listy pasterskie-odezwy-przemówienia, wprowadzenie i edycja dokumentów J. Myszor, Katowice 2013, s. 82n; Por. Akt poświęcenia się młodzieży męskiej Śląska Matce Bożej, w: A . H 1 o n d, Dzieła. Nauczanie 1897-1948, t. I, red. Jan Konieczny, Toruń 2003, s. 113; Por. J . Z b u d n i e w e k, Kardynat August Hlond w dziejach Jasnogórskiego klasztoru i zakonu paulinów, Studia Claromontana 10(1989), s. 92. 
W związku z koronacją obrazu Matki Bożej Piekarskiej, której dokonał nuncjusz apostolski ks. abp Wawrzyniec Lauri 15 sierpnia 1925 roku, a która zgromadziła około ćwierć miliona pielgrzymów, A. Hlond w swoim orędziu podkreśla głęboką pobożność maryjną Ślązaków i ich związek z sanktuarium w Piekarach. Zachęca do przyjęcia wobec Maryi postawy ślubu. „W świętym drżeniu i ze ślubami na ustach ukoronuj, ludu śląski, swą Matkę i Królowę, aby ci Jej Obraz poprzez dymy fabryczne i życiowe opary odtąd jeszcze większym blaskiem świecił, Boże drogi ci wskazując i kierunki”"10. Koronacja ta nie była połączona $\mathrm{z}$ formalnym składaniem ślubów, ale do takiej postawy ofiarowania się Maryi zachęca śląskich pielgrzymów ich biskup.

Podczas koronacji Matki Boskiej Gostyńskiej, która odbyła się 24 czerwca 1928 roku, kardynał Hlond odwołuje się do ślubów lwowskich króla Jana Kazimierza. Chce ślubować Matce Najświętszej, że w na nowo odzyskanej ojczyźnie Polacy podtrzymają cześć dla Królowej Korony Polskiej". Była to pierwsza koronacja Matki Bożej dokonana osobiście przez kardynała. Podczas uroczystości obecny był nuncjusz apostolski F. Marmaggi ${ }^{12}$. Przed tą koronacją odbył się pierwszy w odrodzonej po zaborach Polsce Kongres Maryjny. Kardynał P. Gasperri wyraził gorące uznanie Prymasowi za zwołanie tego kongresu i wyraził nadzieję, że miłość narodu polskiego do Królowej Niebios stanie się jeszcze bardziej żarliwa ${ }^{13}$.

10 A. H l o n d,Orędzie w sprawie koronacji Matki Bożej Piekarskiej, Katowice, dnia 15 sierpnia 1925, w: Ks. August Hlond..., dz. cyt., s. 115; Por. J. B a ń k a, Ks. A. Hlond na Górnym Ślasku, w: Nasza Przyszłość. Studia z dziejów Kościoła i kultury katolickiej w Polsce, red. A. Schletz, Kraków 1974, s. 132.

11 Por. A. H 1 o n d, Z przemówienia na koronacji Matki Boskiej na Świętej Górze w Gostyniu, 20 VI 1928, w: A. Hlond, Dzieła. Nauczanie 1897-1948, ..., dz. cyt., s. 212. Kardynał Hlond dokonał także koronacji obrazu Matki Bożej w Borku na Zdzieżu - 2 lipca 1931, Matki Bożej Pokoju w swoim kościele tytularnym Rzymie 18 listopada 1934 a także statuy Matki Bożej Jazłowieckiej w Jazłowcu - 9 lipca 1939. Por. Acta Hlondiana VI 14, s. 191. Dalej jako AH.

12 Por. M. Wło s e k, Maryjny wymiar duszpasterskiej postugi kardynała Augusta Hlonda, Kraków 2004, s. 165.

13 Por. List ks. kard. P. Gasperri do kard. A. Hlonda Prymasa Polski z okazji Kongresu Mariańskiego i Koronacji Matki Bożej w Gostyniu na Świętej Górze, Watykan 5 czerwca 1928, w: $A H$ VI 15, s. 199. 
W akcie ofiarowania Wielkopolskiej Akcji Katolickiej w opiekę Maryi, Królowej Apostołów dokonanego w Borku podczas zjazdu katolickiego 6-7 lipca 1935 roku wybrzmiało wołanie o umocnienie $\mathrm{w}$ apostolstwie i uczynienie go owocnym, o wyproszenie bezinteresownej miłości do biednych, zbłąkanych braci i sióstr, o gorliwość, która nie zniechęca się przeciwnościami, nie traci odwagi w trudnościach, nie ustaje przy niepowodzeniach ${ }^{14}$.

W maju 1936 roku przybyło na Jasną Górę osiemnaście tysięcy studentów i studentek polskich szkół wyższych. W uroczystej procesji wynieśli oni na szczyt kaplicy cudowny obraz Matki Bożej. Uroczyście ślubowali, że swoje życie i życie narodu zbudują na zasadach Chrystusowych, że wprowadzą te zasady w kulturę narodu, życie społeczne i polityczne ${ }^{15}$.

We wrześniu 1936 roku przybyła na Jasną Górę wielka pielgrzymka Katolickiego Związku Kobiet stanowiącego jedno ze zrzeszeń Akcji Katolickiej. Sześćdziesiąt tysięcy zebranych zawierzyło Matce Najświętszej swoje apostolstwo. Prosiło o ducha gorliwości, moc czynu, męstwo, wytrwanie szczególnie w trudnościach i przeciwieństwach. A. Hlond widział w ich postawie apostolskie ślubowanie, odnowienie przyrzeczenia pracy dla Boga. Było tu zawarte pragnienie przepojenia polskiego życia duchem Chrystusowym, budowania ojczyzny na Bożych zasadach moralnych a także ożywienia ducha apostolstwa i połączenia go z gotowością ofiary i postawą przedsiębiorczości ${ }^{16}$.

Już zatem w okresie międzywojennym, podczas swojej posługi administratora apostolskiego Górnego Śląska a później prymasa Polski, składa A. Hlond w imieniu wielkich rzesz pielgrzymów śluby Matce

14 Por. A. H 1 o n d, Akt ofiarowania Wielkopolskiej Akcji Katolickiej wopieke Maryi, Królowej Apostołów z okazji Zjazdu Katolickiego w Borku 6-7 lipca 1935, w: $A H$ III 01, s. 258.

15 Por. A. H l o n d, Przemówienie do pielgrzymki Katolickiego Związku Kobiet, Jasna Góra, 26 IX 1936, w: A. Hlond, Dzieła. Nauczanie 1897-1948,..., dz. cyt., s. 553; Por. A. S ł o m k a, Rys biograficzny kardynała A. Hlonda, w: A. H 1 o n d, Na straży sumienia narodu. Wybór pism i przemówień, New York 1951, s. XI.

16 Por. A. Hlon d, Przemówienie do pielgrzymki..., art. cyt., w: A. Hlond, Dzieła. Nauczanie 1897-1948..., dz. cyt., s. 554. 
Bożej, albo przynajmniej zachęca zgromadzonych do podjęcia takiego wyzwania. Można dostrzec pewien związek i rozwój między tymi aktami dotyczącymi określonych środowisk (Ślązaków, studentów, kobiet, członków Akcji Katolickiej) a tym, co dokonało się w 1946 roku w wymiarze całego narodu.

\section{4. ŚLUBY JAKO WYRAZ POBOŻNOŚCI MARYJNEJ A. HLONDA}

Głęboką pobożność maryjną wyniósł A. Hlond ze swego rodzinnego domu. Już jako dziecko pielgrzymował z rodzicami i rodzeństwem do Matki Bożej Piekarskiej. W tej pobożności wyraża się istotny element jego polskiej a także śląskiej tożsamości ${ }^{17}$.

Jako młody dwudziestosześcioletni człowiek, w roku swoich święceń kapłańskich, A. Hlond widzi w Maryi Wspomożenie Wiernych. Jej wstawiennicze działanie dostrzega w zwycięstwach chrześcijan pod Wiedniem i Lepanto, w apostolskim dziele ks. Bosko, który wzniósł w Turynie świątynię pod tytułem Auxilium Christianorum, w cudownych uzdrowieniach i duchowych umocnieniach dokonujących się w sanktuarium w Lourdes, w niezliczonych cudach przed obrazem Maryi na Jasnej Górze. Na pierwszym miejscu wymienia jednak niezwykły ratunek, jakiego Polska doznała od Maryi podczas szwedzkiego potopu: „Gdy Polsce groziła zguba od Szwedów i wrogów ościennych, wtenczas z serca króla i narodu wyszło to krótkie wezwanie: Królowo Korony Polskiej, módl się za nami’"18. Pobożność maryjna A. Hlonda jest głęboko związana z duchowością salezjańską. W jej świetle patrzy on na historię Europy, a szczególnie historię Polski. Widzi w niej historię świętą kształtowaną mocą wstawiennictwa Bogurodzicy.

Wśród wielu sanktuariów maryjnych A. Hlond w szczególny sposób ukochał Częstochowę, duchową stolicę Królowej Polski. Tutaj zwoływał najczęściej zjazdy biskupów, zakonników, sióstr

17 Por. I. P o s a d z y, Duch maryjny naszego założyciela, w: AH VI 18, s. 140-143.

18 A. H lon d, Maryja Wspomożenie Wiernych, 1905, w: AH III 06, s. 298-301. 
zakonnych. Tu prowadził rekolekcje dla kapłanów. Tu wreszcie dokonał się wielki triumf maryjnego ducha narodu, gdy milion Polaków u stóp Maryi złożyło w ofierze swoje polskie serca ${ }^{19}$.

\section{ZWIĄZEK MYŚLI A. HLONDA I Z. SZ. FELIŃSKIEGO}

Badając refleksję kardynała Hlonda dotyczącą maryjnych ślubów narodu, można dostrzec jej związek z myślą wielkiego biskupa Warszawy XIX wieku Zygmunta Szczęsnego Felińskiego. Feliński formułuje program religijnego i moralnego odnowienia narodu w kontekście ślubów lwowskich króla Jana Kazimierza. Podkreśla obecne w nich zobowiązanie nie tylko do ożywienia życia religijnego, oczyszczenia obyczajów, ale i ukształtowania życia publicznego w duchu Ewangelii. Wskazuje, że nie zostały one wypełnione w zakresie sprawiedliwości wobec chłopów. Uważa, że do tych narodowych zobowiązań należy powrócić w pełnym ich wymiarze ${ }^{20}$. W myśli obu wielkich biskupów spotykamy połączenie kwestii odnowy moralnej i religijnej, odnowy w wymiarze osobistym i narodowym.

\section{POTRZEBA MORALNEJ I RELIGIJNEJ ODBUDOWY}

W 1946 roku prymas dostrzega ogrom wojennych zniszczeń, krew pomordowanych, powojenną niepewność, bezdomność, choroby, dramat przesiedleń, napięcia związane z przemianą ustroju, wyzwanie materializmu. Wprost pisze o obniżeniu poziomu moralnego, o powojennych plagach zmysłowości i pijaństwa, o uderzającej w świętość polskiej rodziny niewierności małżeńskiej, o rozwodach i walce

19 Por. I. P o s a d z y, art. cyt., s. 140-143.

20 Por. Z.S z. Feli ń s k i, Nawotywanie narodu polskiego do wypetnienia ślubów króla Jana Kazimierza i stanów Rzeczypospolitej, zaprzysiężonych imieniem narodu w archikatedrze lwowskiej roku Pańskiego 1656, w: Miesiac maj z błogostawionym arcybiskupem Felińskim, Warszawa 2001, s. 166-188. 
z nienarodzonymi, o zjawisku nieuczciwości, kradzieży, bandytyzmu, o nienawiści i zemście. W dramatycznych wydarzeniach współczesności dostrzega wezwanie do pokuty w wymiarze indywidualnym i społecznym. Wzywa do współpracy z Chrystusem i Kościołem nad religijnym odnowieniem narodu, które może wpłynąć na przyszłość Europy. W nowych maryjnych ślubach narodu polskiego widzi pomoc w utwierdzeniu ładu Bożego w Rzeczypospolitej, w odnowieniu oblicza ojczyzny ${ }^{21}$. Doceniając dzieło odbudowy ojczyzny, zachęca do podjęcia odbudowy w dziedzinie ducha. Dostrzega związek życia religijnego i moralnego oraz indywidualnego i społecznego. Nie sprzeciwia się przemianom społecznym. Przypomina o obowiązkach pracodawców dotyczących chociażby przekazywania bez zwłoki zapłaty za wykonaną pracę.

Wobec dramatu II wojny światowej prymas stawia zasadnicze pytania: Jak to się stało? Jak to jest możliwe po dziewiętnastu wiekach chrześcijaństwa? W tym kataklizmie widzi konsekwencję odejścia od Chrystusa i jego prawa, apostazji w rodzinie, w kulturze, w życiu społecznym i politycznym. Wobec moralnej pustki w ludzkich duszach na wielkich połaciach Europy, stało się możliwe ubóstwienie własnej rasy, przywrócenie niewolnictwa, gloryfikacja kłamstwa. Kryzysu Europy nie da się przezwyciężyć wyłącznie przy pomocy środków militarnych czy politycznych. Konieczny jest trudny i długi proces rechrystianizacji Europy i chrześcijańskiego odrodzenia człowieka ${ }^{22}$. W okropnościach II wojny światowej widzi konsekwencję apostazji naszego kontynentu.

A. Hlond przypomina stanowcze wezwanie do pokuty obecne w orędziu Matki Boskiej Płaczącej z La Salette. Wezwanie, które zostało potwierdzone i uzupełnione w Lourdes i Fatimie, nabrało, według prymasa, szczególnej aktualności właśnie teraz, gdy ludzkość staje wobec zagłady. Jest przekonany, że polska maryjna dusza zrozumie znaczenie setnej rocznicy objawień z La Salette. Pragnie,

${ }^{21}$ Por. O panowanie..., dz. cyt., s. 201-210.

22 Por. A. H 1 o n d, Myśli dla Polakóww Argentynie, Lourdes 1942, w: A. H 1 o n d, W stużbie..., dz. cyt., s. 182-183. 
by w duchu ślubów jasnogórskich wyprowadziła z niej praktyczne wnioski ${ }^{23}$.

W późniejszych wypowiedziach kardynał nawiązuje do znaczenia aktu poświęcenia. Doceniając pracę redakcji czasopisma Posłaniec Serca Maryi, pisze następujące słowa: Posłaniec Serca Maryi krzepić będzie dusze polskie kultem Bogarodzicy Dziewicy i przyczyni się niewatpliwie do utrwalenia $w$ sercach $i$ życiu narodu panowania Niepokalanego Serca Maryi, któremu Polska oddała się w Częstochowie uroczyście $w$ opieke ${ }^{24}$. W tych słowach zaznacza, że akt oddania jest równocześnie wskazaniem kierunku działania, zadaniem, jakie staje przed polskimi katolikami.

\section{WYTRWANIE WZASIE PRZEŚLADOWAŃ}

Prymas ostrzega przed próbami oderwania narodu od Kościoła, przed pokusą odstępstwa, wyzwaniem ze strony materializmu. Przypomina, że Kościół nie jest wrogiem postępu, wiedzy czy doskonalenia doczesnej cywilizacji, ale prawdziwa nowoczesność powinna wiązać się z rozwojem kultury ducha. Ostrzega, że najbliższe lata mogą zadecydować, czy Polska pozostanie katolicka ${ }^{25}$.

Konferencja Episkopatu Polski z 9-10 września 1946 roku nawiązuje do ślubów jasnogórskich i widzi w nich wielkie pragnienie wytrwania w wierze katolickiej. Wspomina o przejawach łamania wolności Kościoła, o próbach wciągania go w polityczne rozgrywki, wykorzystywania autorytetu księży w walce o władzę. Biskupi piszą o ślubach: Byt to widok wzruszający wszystkich do głębi, a zarazem byt to akt zdecydowanej woli wytrwania w wierze świętej katolickiej,

23 Por. A. H 1 o n d, Stowo Prymasa Polski na stulecie objawienia w La Salette [z dn. 5 sierpnia 1947], Rzeszów 1947, s. 1.

24 A. H lon d, Pismo gratulacyjne 13.05.1947, w: A. H 1 o n d, W stużbie..., dz. cyt., s. 201.

25 Por. O panowanie..., dz. cyt., s. 202-203. 
tej wierze Ojców, która im była zawsze siła zwycięska, w różnych a tak licznych niebezpieczeństwach ubiegtego czasu ${ }^{26}$.

A. Hlond wskazuje Maryję jako Tę, która wspiera nas w trudnościach, przeciwnościach, niepowodzeniach, prześladowaniach, cierpieniach i upadkach: ...gdy nas przeciwności trapia, gdy nas albo prace męcza albo pokusy nagabuja, albo prześladowania ciemięża albo gdy gniew Pański nad nami zawist. Każdy się wtenczas do Niej ucieka wzywając Ja pod różnymi tytułami: Uzdrowienie chorych, Ucieczko grzesznych, Pocieszycielko strapionych, módl się za nami ${ }^{27}$.

Prymas jest świadomy komunistycznej metody walki z Kościołem opierającej się przede wszystkim na stopniowym, powolnym prześladowaniu, które ma doprowadzić do załamania się człowieka i narodu. Odpowiedzią jest oddanie się Matce Najświętszej, które chroni człowieka przez zniechęceniem, załamaniem i rozpaczą.

\section{CZAS, W KTÓRYM ROZSTRZYGA SIE PRZYSZLOŚĆ OJCZYZNY I ŚWIATA}

W akcie poświęcenia się narodu polskiego Niepokalanemu Sercu Maryi prymas dostrzega wagę historycznych wydarzeń, szczególny czas, w którym rozstrzyga się przyszłość. Ten akt poświęcenia dotyczy osoby, narodu i państwa. Jest obietnicą wierności Chrystusowi. Stanowi prośbę skierowaną do Maryi o opiekę nad polską rodziną, narodem, państwem, nad parafią, kapłanami, papieżem, Kościołem. Ważną jego część stanowi modlitwa za błądzących, za narody, które odeszły od Boga i za te, które odłączyły się od Kościoła ${ }^{28}$.

W wizji A. Hlonda naród polski i świat są ze sobą powiązane. Odnowa moralna i religijna naszego kraju ma wielkie znaczenie dla

${ }^{26}$ Komunikat z plenarnej Konferencji Episkopatu odbytej na Jasnej Górze w Częstochowie 9-10 września 1946 r., w: AH I 02, s. 261.

27 A. H lo n d, Maryja..., art. cyt., w: AH III 06, s. 298-299.

28 Por. A. H lo n d, Akt poświęcenia się narodu polskiego Niepokalanemu Sercu Maryi, Jasna Góra, 8 września 1946, w: A . H 1 o n d, Daj mi dusze. Wybór pism i przemówień 1897-1948, oprac. S. Kosiński, Łódź 1979, s. 292-293. 
całej ludzkości. Polska ma swoje dziejowe posłannictwo. Może stać się przewodniczką dla innych narodów. Jeżeli spetnimy ślubowania jasnogórskie... stworzymy warunki duchowe prymatu narodu. Petne chrześcijaństwo w Polsce ma być zapowiedzia rechrystianizacji świata. Mocarna wiara wyzwólmy u siebie i sasiadów wielkość ducha, uwięziona i tlukąca się w próżniach ideowych ${ }^{29}$.

Matka Boża wzywa nas do służby, którą nam w nowym świecie wyznacza. Chodzi o wyzwalanie prawdą dusz uwikłanych w błędach. W ten sposób Polska ma odnawiać królestwo Niepokalanego Serca Maryi. Narodowa służba maryjna Polaków ma znaczenie dla odnowy narodów słowiańskich ${ }^{30}$.

\section{NASZA PRZYSZLOŚĆ W RĘKACH MARYI}

Podczas II wojny światowej A. Hlond, odwołując się do Najświętszej Maryi Panny, stara się umacniać nadzieję wiernych, że przyszła, odrodzona Rzeczpospolita będzie lepsza i szczęśliwsza ${ }^{31}$.

Szczególnie u schyłku życia prymas z zaufaniem i nadzieją spogląda ku Maryi. Zachęca do odmawiania i propagowania modlitwy różańcowej. Wzywa: „Nie obawiajcie się mocy złych. Matka Najświętsza da zwycięstwo Kościołowi. I nam gotuje wielkie zwycięstwo i przyszłość wielką i Bożąa"32. Jest świadomy zasadniczych zmian, jakie dokonują się w kraju i w świecie. Zmianie ulegają państwa, ustroje i człowiek. Jednak chociaż wiele rzeczy ginie, to są rzeczy, które zginąć nie mogą. Woła: ,idziemy w nowe czasy z tą Najśw. Maryją Panną, która nam przez wieki była Przewodniczką, Matką

29 A. H lo nd, List pasterski na 950-lecie śmierci św. Wojciecha, Warszawa 10.03.1947, w: A. H lo n d, Na straży..., dz. cyt., s. 179.

30 Por. A. H lo nd, W stużbie..., dz. cyt., s. 232.

${ }^{31}$ Por. A. H 1 o n d, Z listu do Zofii Gordziałkowskiej, Lourdes, 7 IV 1942, w: A. H lon d, Sanctificemini Adhuc. Wybór myśli z korespondencji 1939-1948, cz. I, oprac. S. Kosiński, Ląd 1976, s. 204.

32 Przemówienie podczas Kongresu Kółek Różańcowych, Krasnobród, 1 VII 1948 [streszczenie], w: A . H lo n d, Dzieła. Nauczanie 1897-1948..., dz. cyt., s. 879. 
i Królową"33. Zachęca do odmawiania różańca odwołując się do objawień w Lourdes i w Fatimie. „Bo tej Matki potrzebujemy, bo ta przyszłość idzie, a ta przyszłość będzie lepsza, bo wykrzesana tą Wszechmocą, którą Bóg w naszych czasach w ręce Matki Najświętszej składa. Ona tę wszechmoc wieczną dzierży w swym ręku. Ona kierunki nadawać będzie światu. Ona narody poprowadzi tą Wszechmocą Bożą, której staje się na lata najbliższe szafarką"34. To jedno z ostatnich przemówień prymasa jest jakby formą ślubowania, przysięgą wierności Bogu i Matce Najświętszej. Podczas ostatniego publicznego wystąpienia A. Hlond dostrzega czas szczególny, czas zbawienia, w którym wyjątkową rolę odegra Maryja: „I dzisiaj, gdy nadchodzi godzina, że wszystko jest w rękach Matki Najświętszej, błagajmy Ją o ratunek dla świata codzienną modlitwą różańcową, a Ona Zwiastunka życia - poprowadzi nas do Zbawiciela"35.

\section{ODDZIALYWANIE MYŚLI A. HLONDA}

W pierwszą rocznicę aktu poświęcenia, a więc 8 września 1947 roku Episkopat Polski ponownie zgromadził się na Jasnej Górze, by wraz z setkami tysięcy pielgrzymów oddawać cześć Niepokalanemu Sercu Najświętszej Maryi Panny. Od pamiętnego września 1946 roku polscy biskupi odprawiają swoje doroczne rekolekcje na Jasnej Górze w pierwszych dniach września przed kolejną rocznicą poświęcenia narodu ${ }^{36}$.

Najbardziej znane są słowa Sługi Bożego wypowiedziane na łożu śmierci 22 października 1948 roku. Mówił o nich Stefan Wyszyński, podkreślając, że on sam uważa się tylko za realizatora wizji swojego

33 A. H lo n d, Przemówienie podczas poświęcenia statuy NMP we Wrocławiu, Wrocław, 22 IX 1948, w: A. H 1 o n d, Dzieła. Nauczanie 1897-1948..., dz. cyt., s. 887.

34 Tamże, s. 888.

35 A. H 1 o n d, Przemówienie podczas uroczystego przeniesienia relikwii bt. Władysława z Gielniowa, Warszawa, kościół akademicki św. Anny, 12 X 1948, w: A. H 1 o n d, Dzieła. Nauczanie 1897-1948..., dz. cyt., s. 889.

36 Por. L. Balter, art. cyt., s. 9-14. 
poprzednika. „On [August Hlond] to bowiem powiedział: «Zwycięstwo, gdy przyjdzie, będzie to zwycięstwo Matki Najświętszej». Ja jestem tylko wykonawcą jego programu. Pracuję nad tym, aby to zwycięstwo przyszło i aby było to zwycięstwo Matki Najświętszej. Ono przyjdzie i będzie Jej zwycięstwem. Dlatego wasze kwiaty pójdą na grób tego polskiego proroka, który gasnącymi oczyma i słabnącymi wargami zapowiadał zwycięstwo Matki Najświętszej"37. W tych słowach Prymas Tysiąclecia wskazuje na bliski związek swoich inicjatyw maryjnych z myślą wielkiego poprzednika.

\section{PODSUMOWANIE}

W 1946 roku, po zakończeniu II wojny światowej i w obliczu zagrożenia ze strony komunistycznego ateizmu, z inicjatywy prymasa Polski Augusta Hlonda dokonał się akt poświęcenia narodu Niepokalanemu Sercu Maryi. Patrząc na genezę tego wydarzenia, możemy dostrzec przede wszystkim nawiązanie z jednej strony do ślubów króla Jana Kazimierza, z drugiej do objawień z Fatimy stanowiących wezwanie do poświęcenia ludzkości Niepokalanemu Sercu Maryi. Prymas dostrzega czas wojennych zniszczeń i nowych niebezpieczeństw związanych szczególnie z ateistycznym komunizmem, czas, w którym w szczególny sposób uwidacznia się potrzeba moralnej i religijnej odnowy narodu. Wybory Polski i Polaków mają istotne znaczenie dla naszych słowiańskich sąsiadów i całego świata. W sytuacji gwałtownych ustrojowych zmian Sługa Boży patrzy z nadzieją w przyszłość Kościoła, Polski i świata. Przyszłość tę widzi w Maryi, która może obronić Kościół przed mocami ciemności i przynieść mu zwycięstwo.

37 S. W y s z y ń s k i, Kazanie wygłoszone podczas poświęcenia chrzcielnicy Tysiąclecia, Niepokalanów, 31 maja 1965, w: S. Wyszyński, Nie gaście ducha ojca Maksymiliana. Wybór przemówień i listów, Niepokalanów 1996, s. 79. 


\section{Summary}

Act of Entrustment of the Nation to the Immaculate Heart of Our LAdy aCCORding to A. HLOND

In 1946, after the end of the II World War, in view of the menaces linked to communist atheism an act of entrustment of the nation to the Immaculate Heart of Our Lady was performed on the initiative of the Primate of Poland August Hlond. Looking at the origins of the event, on the one hand we can see the reference to the oath of King John II Casimir Vasa, and on the other hand to the revelations of Fatima, which are an encouragement to entrust humanity to the Immaculate Heart of Mary. A. Hlond sees the urgency of moral and religious renewal of the nation in the times of damages caused by war and new dangers linked to communist atheism. Choices made by Poland and Poles have a particular meaning for our Slavic neighbours and the whole world. In the period of violent political changes, A. Hlond looks at the future of the Church, Poland and the world with hope. It is Mary who can secure the future and protect the Church from the powers of darkness and bring victory.

Słowa kluczowe: Hlond August, mariologia, akt poświęcenia narodu, Niepokalane Serce Maryi

Key words: Hlond August, Mariology, the act of entrustment of the nation, The Immaculate Heart of Our Lady

\section{Bibliografia}

AH - Acta Hlondiana, t. I, III, VI.

B a 1 t e r L ., Rok 1946 na Jasnej Górze, „Jasna Góra” 9(11), s. 9-14.

D r o z d J., Orędzie Niepokalanej. Historia i sens objawień fatimskich, Kraków 1996.

H 1 o n d A ., Daj mi dusze. Wybór pism i przemówień 1897-1948, oprac. S. Kosiński, Łódź 1979.

H lon d A ., Dzieła. Nauczanie 1897-1948, t. I, red. Jan Konieczny, Toruń 2003.

H 1 on d A ., Na straży sumienia narodu. Wybór pism i przemówień, New York 1951.

H 1 on d A ., Sanctificemini Adhuc. Wybór myśli z korespondencji 1939-1948, cz. I, oprac. S. Kosiński, Ląd 1976.

H lond A., Stowo Prymasa Polski na stulecie objawienia w La Salette [z dn. 5 sierpnia 1947], Rzeszów 1947.

H lond A.,W stużbie Boga i Ojczyzny. Wybór pism i przemówień 1922-1948, oprac. S. Kosiński, Warszawa 1988. 
H 1 ond A ., Z Chrystusem w życie. Okruchy myślowe 1922-1948, oprac. S. Kosiński, Łódź 1981.

Ko s iń s k i S., Maryjno-społeczna myśl kardynata Augusta Hlonda, Studia Claromontana 10(1989), s. 76-90.

Ks. August Hlond na Górnym Śląsku 1922-1926. Listy pasterskie-odezwy-przemówienia, wprowadzenie i edycja dokumentów J. Myszor, Katowice 2013.

Ks. kardynat August Hlond - społeczny wymiar nauczania, red. G. Polok, Katowice 2006.

Miesią maj z błogosławionym arcybiskupem Felińskim, Warszawa 2001.

P i t r zak J., Petnia prymasostwa. Ostatnie lata prymasa Polski kardynata Augusta Hlonda 1945-1948, t. I, Poznań 2009,

W ło se k M., Maryjny wymiar duszpasterskiej postugi kardynała Augusta Hlonda, Kraków 2004.

W y s z y ń s k i S., Nie gaście ducha ojca Maksymiliana. Wybór przemówień i listów, Niepokalanów 1996.

$\mathrm{Z}$ b u d n i e w e k J ., Kardynat August Hlond w dziejach Jasnogórskiego klasztoru i zakonu paulinów, Studia Claromontana 10(1989), s. 91-183.

Z i m n i a S ., Zwycięstwo Maryi. Proroctwo Kardynata Augusta Hlonda. W postudze apostolskiej prymasa tysiaclecia Stefana kardynała Wyszyńskiego i papieża Jana Pawła II Wielkiego, Warszawa 2007.

Ks. Grzegorz Bachanek - kapłan archidiecezji warszawskiej, dr hab. teologii dogmatycznej, adiunkt w Katedrze Mariologii Wydziału Teologicznego UKSW w Warszawie, autor książek Josepha Ratzingera nauka o Kościele (Warszawa 2005) oraz Teologiczna odpowiedź Zygmunta Szczęsnego Felińskiego na zagrożenia Kościoła w czasach zaborów (Niepokalanów 2015). 